\title{
ABSORPTION, DISTRIBUTION AND EXCRETION OF CEFSULODIN, AN ANTIPSEUDOMONAL CEPHALOSPORIN, IN MICE, RATS AND DOGS
}

\author{
Kanji Tsuchiya, Hiroshi Nagatomo, Masahiro Kondo, \\ Yasuo Kita and TAKeshi Fugono \\ Central Research Division, Takeda Chemical Industries, Ltd. \\ Osaka, Japan
}

(Received for publication March 24, 1978)

\begin{abstract}
A single dose of $20 \mathrm{mg} / \mathrm{kg}$ of cefsulodin [3-(4-carbamoyl-1-pyridiniomethyl)-7 $\beta$-(D- $\alpha$ sulfophenylacetamido)-ceph-3-em-4-carboxylate monosodium salt] was administered subcutaneously to mice, and intramuscularly to rats and dogs. The plasma and tissue levels reached the peak 15 30 minutes after administration. In mice and rats, no plasma levels were measurable 2 and 4 hours after administration. In dogs, the plasma levels were measurable 6 hours after administration. The level in the kidney of mice was slightly lower than the plasma level, while in rats and dogs, the level in the kidney was higher than the plasma level. The cefsulodin levels in the lung of rats and dogs were relatively high, and the level in mice was relatively low. The hepatic levels were very low in all test animal species. Cefsulodin was mainly excreted into the urine, and the excretion of cefsulodin into the bile was very slight.
\end{abstract}

Cefsulodin [3-(4-carbamoyl-1-pyridiniomethyl)-7 $\alpha$-(D- $\alpha$-sulfophenylacetamido)-ceph-3-em-4-carboxylate monosodium salt] (Fig. 1), a new antipseudomonal cephalosporin, has a potent in vitro and in vivo activity against major strains of gentamicin-sensitive and -resistant Pseudomonas aeruginosa, and it is also active against certain gram-positive organisms ${ }^{1,2}$.

It was thought important, therefore, to study plasma levels, tissue distribution, and urinary and biliary excretion of cefsulodin in several species of experimental animals.

Fig. 1. Chemical structure of cefsulodin

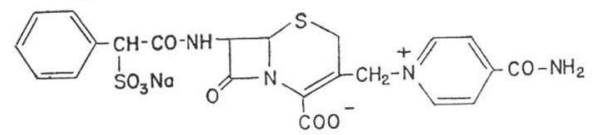

\section{Materials and Methods}

Antibiotic. Cefsulodin was prepared in Takeda Chemical Industries, Ltd. A single dose of $20 \mathrm{mg} /$ $\mathrm{kg}$ of cefsulodin dissolved in saline was administered subcutaneously to mice and intramuscularly to rats and dogs.

Animals. Four-week-old male SLC-ddY mice weighing 19 23 g, 11-week-old male JCL-Sprague Dawly rats weighing $350 \sim 450 \mathrm{~g}$ and male mongrel dogs weighing $9 \sim 12 \mathrm{~kg}$ were used.

Specimens for Cefsulodin Assay. Plasma was separated by centrifugation from the heparinized blood sample. A small portion of each tissue was homogenized with a 2-fold volume of $1 / 15 \mathrm{M}$ phosphate buffer solution pH 7 (PBS) using a homogenizer. The homogenate was centrifuged at 3,000 r.p.m. for 10 minutes and supernatant was assayed. Recovery rates of cefsulodin from each tissue homogenate were higher than $95 \%$ by the test with tissue homogenates mixed with a final concentration of $20 \mu \mathrm{g}$ of cefsulodin per $\mathrm{ml}$. Urine samples were collected with a metabolism cage from mice and rats, and with a urethral catheter from rats and dogs. Bile samples were collected from the common bile duct cannulated with polyethylene tube in animals anesthetized with pentobarbital. All samples were stored at $-20^{\circ} \mathrm{C}$ until use.

Cefsulodin Assay. The cefsulodin concentration of each specimen was assayed using cylinder- 
plate diffusion technique with P. aeruginosa NCTC 10490 as a test organism and DST agar (Oxoid). Cefsulodin in plasma was assayed without dilution, and cefsulodin concentration in plasma was calculated from the standard curve of the cefsulodin in plasma. Urine and bile samples were diluted with PBS so that the final concentrations of cefsulodin were lower than $40 \mu \mathrm{g} / \mathrm{ml}$. Cefsulodin activity was not affected by more than 5 times diluted urine and bile. Cefsulodin concentrations in the diluted specimens and the supernatants of tissue homogenates were calculated from the standard of cefsulodin dissolved in PBS. The concentration of standard solutions of cefsulodin dissolved in plasma or PBS was $0.625 \sim 40 \mu \mathrm{g} / \mathrm{ml}$, and the lowest quantifiable concentration in samples was $0.2 \mu \mathrm{g} / \mathrm{ml}$.

\section{Results}

Mice.

The peaks of the levels in plasma and tissue were observed 15 minutes after administration. The plasma level declined rapidly, and cefsulodin disappeared 2 hours after administration. The level of cefsulodin in the kidney was slightly lower than the plasma level; quite low in the lung 15 and 30 minutes after administration. No cephalosporin was observed in the liver, spleen and brain (Table 1).

Mean urinary levels of cefsulodin within 8 hours and between 8 and 24 hours after administration were 654 and $11.7 \mu \mathrm{g} / \mathrm{ml}$, respectively. Mean values of urinary excretion were $64.8 \%$ of the given dose within 8 hours and $5.4 \%$ of the given dose between 8 and 24 hours after administration (Table 2).

Table 1. Plasma and tissue level of cefsulodin after a single subcutaneous dose of $20 \mathrm{mg} / \mathrm{kg}$ in mice $(n=6)$

\begin{tabular}{l|c|c|c|c}
\hline \multirow{2}{*}{ Tissue } & \multicolumn{4}{|c}{$\begin{array}{c}\text { Concentration in } \mu \mathrm{g} / \mathrm{ml} \text { or } \mathrm{g} \\
\text { (Mean } \pm \text { S.D.) }\end{array}$} \\
\cline { 2 - 5 } & $1 / 4$ hour & $1 / 2$ hour & 1 hour & 2 hours \\
\hline Plasma & $20.2 \pm 4.7$ & $15.8 \pm 5.5$ & $4.7 \pm 1.1$ & 0 \\
Lung & $2.2 \pm 1.8$ & $1.4 \pm 1.0$ & 0 & 0 \\
Liver & 0 & 0 & 0 & 0 \\
Spleen & 0 & 0 & 0 & 0 \\
Kidney & $18.9 \pm 3.7$ & $13.4 \pm 3.3$ & $4.9 \pm 1.6$ & 0 \\
Brain & 0 & 0 & 0 & 0 \\
\hline
\end{tabular}

Table 2. Urinary level and excretion of cefsulodin after a single subcutaneous dose of $20 \mathrm{mg} / \mathrm{kg}$ in mice $(\mathrm{n}=10)$

\begin{tabular}{|c|c|c|}
\hline $\begin{array}{c}\text { Time } \\
\text { (Hour) }\end{array}$ & $\begin{array}{c}\text { Concentration in } \\
\mu \mathrm{g} / \mathrm{ml} \\
\text { (Mean } \pm \text { S.D.) }\end{array}$ & $\begin{array}{c}\text { Excretion } \\
\text { percentage } \\
\text { (Mean } \pm \text { S.D.) }\end{array}$ \\
\hline $0 \sim 8$ & $654 \pm 171$ & $64.8 \pm 19.7$ \\
\hline $8 \sim 24$ & $11.7 \pm 5.0$ & $5.4 \pm 2.8$ \\
\hline \multicolumn{2}{|l|}{ Total } & $72.0 \pm 17.8$ \\
\hline
\end{tabular}

Rats.

The plasma and tissue levels reached the peak 15 minutes after administration and thereafter the levels declined rapidly. The plasma level was $44.9 \mu \mathrm{g} / \mathrm{ml}$ at the peak and cefsulodin disappeared from the plasma 4 hours after administration. The renal level of cefsulodin was about 2 times higher than

Table 3. Plasma and tissue level of cefsulodin after a single intramuscular dose of $20 \mathrm{mg} / \mathrm{kg}$ in rats $(\mathrm{n}=4)$

\begin{tabular}{l|c|c|c|c|c}
\hline \multirow{2}{*}{ Tissue } & \multicolumn{5}{|c}{ Concentration in $\mu \mathrm{g} / \mathrm{ml}$ or g (Mean \pm S. D.) } \\
\cline { 2 - 6 } & $1 / 4$ hour & $1 / 2$ hour & 1 hour & 2 hours & 4 hours \\
\hline Plasma & $44.9 \pm 2.5$ & $31.3 \pm 5.2$ & $15.4 \pm 5.0$ & $1.3 \pm 0.9$ & 0 \\
Lung & $12.6 \pm 3.6$ & $7.8 \pm 1.5$ & $2.7 \pm 1.5$ & 0 & 0 \\
Liver & $4.3 \pm 1.3$ & $4.0 \pm 1.3$ & $1.6 \pm 0.6$ & 0 & 0 \\
Spleen & $2.2 \pm 0.6$ & $1.6 \pm 0.2$ & 0 & 0 & 0 \\
Kidney & $78.3 \pm 32.3$ & $53.1 \pm 2.4$ & $36.6 \pm 4.4$ & $10.3 \pm 2.8$ & $1.8 \pm 0.3$ \\
Brain & 0 & 0 & 0 & 0 & 0 \\
\hline
\end{tabular}


the plasma level during an hour after administration and the cephalosporin was detected 4 hours after administration in the kidney. The pulmonary level was $12.6 \mu \mathrm{g} / \mathrm{g}$ at the peak and cefsulodin disappeared 2 hours after administration. Quite a low level of cefsulodin was obtained in the liver and spleen. No cephalosporin was observed in the brain (Table 3).

In unanesthetized rats, mean urinary levels of cefsulodin within 8 hours and between 8 and 24 hours after administration were 770 and $32 \mu \mathrm{g} / \mathrm{ml}$, respectively. Mean values of urinary excretion were $79.8 \%$ of the given dose within 8 hours and $8.1 \%$ of the given dose between 8 and 24 hours after administration. In anesthetized bile-duct cannulated rats, mean value of urinary excretion was $71.9 \%$ of the given dose within 6 hours after administration. Urinary excretion of cefsulodin within 6 hours after administration in unanesthetized and anesthetized bile-duct cannulated rats was almost the same (Table 4). Mean value of biliary excretion was $1.03 \%$ of the given dose within 6 hours after administration (Table 5). The excretion of cefsulodin was rapid and the major part of the cephalosporin was excreted into the urine and bile within 2 hours after administration.

Table 4. Urinary level and excretion of cefsulodin after a single intramuscular dose of $20 \mathrm{mg} / \mathrm{kg}$ in rats

\begin{tabular}{c|c|c|c}
\hline $\begin{array}{c}\text { Anesthe- } \\
\text { tization }\end{array}$ & $\begin{array}{c}\text { Time } \\
(\text { Hour })\end{array}$ & $\begin{array}{c}\text { Concentration } \\
\text { in } \mu \mathrm{g} / \mathrm{ml} \\
\text { (Mean } \pm \text { S.D. }\end{array}$ & $\begin{array}{c}\text { Excretion } \\
\text { percentage } \\
\text { (Mean } \pm \text { S.D. })\end{array}$ \\
\hline \multirow{2}{*}{$\begin{array}{c}\text { - } \\
(\mathrm{n}=6)\end{array}$} & $0 \sim 8$ & $774 \pm 134$ & $79.8 \pm 7.2$ \\
& $8 \sim 24$ & $31.6 \pm 17.3$ & $8.1 \pm 4.1$ \\
\cline { 2 - 4 } & \multicolumn{2}{|c|}{ Total } & $87.9 \pm 3.4$ \\
\hline \multirow{3}{*}{$(\mathrm{n}=6)$} & $0 \sim 2$ & $5,620 \pm 808$ & $41.4 \pm 7.5$ \\
& $2 \sim 4$ & $2,260 \pm 465$ & $17.5 \pm 4.6$ \\
& $4 \sim 6$ & $917 \pm 339$ & $13.0 \pm 5.3$ \\
\cline { 2 - 4 } & \multicolumn{2}{|c|}{ Total } & $71.9 \pm 2.1$ \\
\hline
\end{tabular}

Table 5. Biliary level and excretion of cefsulodin after a single intramuscular dose of $20 \mathrm{mg} / \mathrm{kg}$ in rats

\begin{tabular}{c|c|r|c}
\hline $\begin{array}{c}\text { Anesthe- } \\
\text { tization }\end{array}$ & $\begin{array}{c}\text { Time } \\
\text { (Hour) }\end{array}$ & $\begin{array}{c}\text { Concentration } \\
\text { in } \mu \mathrm{g} / \mathrm{ml} \\
(\text { Mean } \pm \text { S.D. }\end{array}$ & $\begin{array}{c}\text { Excretion } \\
\text { percentage } \\
\text { (Mean } \pm \text { S.D. })\end{array}$ \\
\hline \multirow{3}{*}{$\begin{array}{c}+ \\
(\mathrm{n}=6)\end{array}$} & $0 \sim 2$ & $25.4 \pm 6.0$ & $0.81 \pm 0.3$ \\
& $2 \sim 4$ & $6.0 \pm 3.0$ & $0.17 \pm 0.1$ \\
\cline { 2 - 4 } & $4 \sim 6$ & $1.5 \pm 0.9$ & $0.05 \pm 0.03$ \\
\cline { 2 - 4 } & \multicolumn{2}{|c|}{ Total } & $1.03 \pm 0.38$ \\
\hline
\end{tabular}

Dogs.

The peaks of levels in plasma and tissue appeared 30 minutes after administration and thereafter the levels declined gradually. The concentration of cefsulodin at 30 minutes after administration was in the diminishing order kidney $(82.6 \mu \mathrm{g} / \mathrm{g})$, plasma $(38.6 \mu \mathrm{g} / \mathrm{ml})$, lung $(12.8 \mu \mathrm{g} / \mathrm{g})$, spleen $(3.1 \mu \mathrm{g} / \mathrm{g})$ and liver $(2.3 \mu \mathrm{g} / \mathrm{g})$ (Table 6).

Table 6. Plasma and tissue level of cefsulodin after a single intramuscular dose of $20 \mathrm{mg} / \mathrm{kg}$ in dogs $(\mathrm{n}=5)$

\begin{tabular}{l|c|c|c|c|c}
\hline \multirow{2}{*}{ Tissue } & \multicolumn{5}{|c}{ Concentration in $\mu \mathrm{g} / \mathrm{ml}$ or $\mathrm{g}$ (Mean \pm S.D.) } \\
\cline { 2 - 6 } & $1 / 2$ hour & 1 hour & 2 hours & 4 hours & 8 hours \\
\hline Plasma & $38.6 \pm 3.9$ & $25.2 \pm 3.9$ & $9.4 \pm 3.1$ & $0.5 \pm 0.5$ & 0 \\
Lung & $12.8 \pm 3.0$ & $8.0 \pm 3.0$ & $1.3 \pm 1.0$ & 0 & 0 \\
Liver & $2.3 \pm 1.3$ & $1.8 \pm 0.5$ & 0 & 0 & 0 \\
Spleen & $3.1 \pm 2.0$ & $2.3 \pm 1.0$ & 0 & 0 & 0 \\
Kidney & $82.6 \pm 27.3$ & $72.7 \pm 11.4$ & $15.1 \pm 3.2$ & $6.2 \pm 2.3$ & 3.0 \\
Brain & 0 & 0 & 0 & 0 & 0 \\
\hline
\end{tabular}


Table 7. Plasma level of cefsulodin after a single intramuscular dose of $20 \mathrm{mg} / \mathrm{kg}$ in dogs

\begin{tabular}{c|c|c|c|c|c|c}
\hline \multirow{2}{*}{ Anesthetization } & \multicolumn{6}{|c}{ Concentration in $\mu \mathrm{g} / \mathrm{ml}($ Mean \pm S. D.) } \\
\cline { 2 - 7 } & $1 / 4$ hour & $1 / 2$ hour & 1 hour & 2 hours & 4 hours & 6 hours \\
\hline$-(\mathrm{n}=6)$ & $38.0 \pm 10.8$ & $37.2 \pm 8.0$ & $30.2 \pm 5.7$ & $19.1 \pm 5.3$ & $3.1 \pm 0.8$ & 0.2 \\
$+(\mathrm{n}=5)$ & $27.9 \pm 17.5$ & $31.4 \pm 6.4$ & $26.3 \pm 5.3$ & $18.9 \pm 6.3$ & $5.2 \pm 1.9$ & $1.7 \pm 0.4$ \\
\hline
\end{tabular}

Table 8. Urinary level and excretion of cefsulodin after a single intramuscular dose of $20 \mathrm{mg} / \mathrm{kg}$ in dogs

\begin{tabular}{c|c|c|c}
\hline $\begin{array}{c}\text { Anesthe- } \\
\text { tization }\end{array}$ & $\begin{array}{c}\text { Time } \\
\text { (Hour) }\end{array}$ & $\begin{array}{c}\text { Concentration } \\
\text { in } \mu \mathrm{g} / \mathrm{ml} \\
(\text { Mean } \pm \text { S.D. }\end{array}$ & $\begin{array}{c}\text { Excretion } \\
\text { percentage } \\
(\text { Mean } \pm \text { S.D. })\end{array}$ \\
\hline \multirow{3}{*}{$\begin{array}{c}+ \\
(n=5)\end{array}$} & $0 \sim 2$ & $7,720 \pm 1,720$ & $55.4 \pm 6.0$ \\
& $2 \sim 4$ & $4,380 \pm 600$ & $25.0 \pm 5.1$ \\
& $4 \sim 6$ & $1,690 \pm 320$ & $8.0 \pm 1.2$ \\
\cline { 2 - 4 } & \multicolumn{2}{|c|}{ Total } & $88.3 \pm 7.9$ \\
\hline
\end{tabular}

Table 9. Biliary level and excretion of cefsulodin after a single intramuscular dose of $20 \mathrm{mg} / \mathrm{kg}$ in dogs

\begin{tabular}{c|c|c|c}
\hline $\begin{array}{c}\text { Anesthe- } \\
\text { tization }\end{array}$ & $\begin{array}{c}\text { Time } \\
\text { (Hour) }\end{array}$ & $\begin{array}{c}\text { Concentration } \\
\text { in } \mu \mathrm{g} / \mathrm{ml} \\
\text { (Mean } \pm \text { S.D. }\end{array}$ & $\begin{array}{c}\text { Excretion } \\
\text { percentage } \\
\text { (Mean } \pm \text { S.D. })\end{array}$ \\
\hline \multirow{3}{*}{$\begin{array}{c}\text { Men } \\
(\mathrm{n}=5)\end{array}$} & $0 \sim 1$ & $3.2 \pm 2.2$ & $0.002 \pm 0.002$ \\
& $1 \sim 2$ & $31.2 \pm 22.9$ & $0.02 \pm 0.01$ \\
& $2 \sim 4$ & $54.0 \pm 27.1$ & $0.04 \pm 0.02$ \\
\cline { 2 - 4 } & $4 \sim 6$ & $46.6 \pm 16.2$ & $0.03 \pm 0.01$ \\
\cline { 2 - 4 } & \multicolumn{2}{|l}{ Total } & $0.09 \pm 0.03$ \\
\hline
\end{tabular}

When blood samples were collected consecutively from the same animals, the peak level in plasma of cefsulodin in anesthetized bile-duct cannulated dogs was slightly lower than in unanesthetized animals, and the plasma level of cefsulodin in anesthetized bile-duct cannulated dogs decreased more slowly (Table 7). In anesthetized bile-duct cannulated dogs, the mean values of urinary and biliary excretion were $88.3 \%$ and $0.09 \%$ of the given dose within 6 hours of administration, respectively. The major part of the dose was excreted within 2 hours after administration. The mean value of urinary excretion between 4 and 6 hours after administration was $8 \%$ of the dose. The urinary and biliary concentrations of cefsulodin during the observation period were much higher than minimum inhibitory concentration for many strains of $P$. aeruginosa (Tables 8 and 9).

\section{Discussion}

Chemical structure of cefsulodin, a new antipseudomonal cephalosporin, resembles that of sulbenicillin in that the former has the sulfophenyl group at the 7-position of the cephem ring and the latter has the same group at the 6-position on the penam ring ${ }^{3,4}$, and both antibiotics have antibacterial activity against $P$. aeruginos $a^{1,2)}$. However, the distribution pattern of cefsulodin in experimental animals is much different from that of sulbenicillin ${ }^{5 \sim 8)}$, but rather resembles that of other cephalosporins.

In this study, cefsulodin showed maximum plasma and tissue levels $15 \sim 30$ minutes after administration of a single dose of $20 \mathrm{mg} / \mathrm{kg}$. In mice, the renal level of cefsulodin was slightly lower than the plasma level, and in rats and dogs, the renal level of cefsulodin was higher than the plasma level. The concentration of cefsulodin in the lung was relatively high in rats and dogs. On the other hand, the hepatic level was very low in all test animal species.

The main route of excretion of cefsulodin is the urinary tract. About $80 \%$ of cefsulodin is excreted into the urine. The renal excretion of cefsulodin is much higher than the biliary excretion as in other cephalosporins. Sulbenicillin showed, however, relatively higher biliary excretion than the urinary excretion in rats ${ }^{9}$ and rabbits ${ }^{7}$, and especially in dogs ${ }^{7}$.

\section{References}

1) Tsuchiya, K.; M. Kondo \& H. Nagatomo: SCE-129, antipseudomonal cephalosporin: In vitro and 
in vivo antibacterial activities. Antimicr. Agents \& Chemoth. 13: 137 145, 1978

2) TsuchiyA, K. \& M. Kondo: Comparative in vitro activities of SCE-129, sulbenicillin, gentamicin and dibekacin against Pseudomonas. Antimicr. Agents \& Chemoth. 13: 536 539, 1978

3) Morimoto, S.; H. Nomura, T. Ishiguro, T. Fugono \& K. Maeda: Semisynthetic $\beta$-lactam antibiotics. I. Acylation of 6-aminopenicillanic acid with activated derivatives of $\alpha$-sulfophenylacetic acid. J. Med. Chem. 15: 1105 1108, 1972

4) Nomura, H.; T. Fugono, T. Hitaka, I. Minami, T. Azuma, S. Morimoto \& T. Masuda: Semisynthetic $\beta$-lactam antibiotics. 6. Sulfocephalosporins and their antipseudomonal activities. J. Med. Chem. 17: $1312 \sim 1315,1974$

5) Tsuchiya, K.; T. Yamazaki, A. Kuchimura \& T. Fugono: Absorption, excretion and tissue distribution of sulbenicillin administered parenterally in mice, rats, rabbits and dogs. J. Antibiotics 25: 336 342, 1972

6) Yamazaki, T.; T. Ihara, T. Sugitani, M. Mizutani, T. Fugono, K. Kamiya \& K. Tsuchiya: Distribution and excretion of sulbenicillin administered intravenously to cynomolgus monkeys. J. Takeda Res. Labs. 34: 393 404, 1975

7) Yamazaki, T.; T. Fugono \& K. Tsuchiya: Distribution and excretion of sulbenicillin administered intravenously to beagle dogs. J. Takeda Res. Labs. 35: 211 216, 1976

8) Yamazaki, T.; T. Fugono, K. Kamiya \& K. Tsuchiya: Concentration in plasma and excretion of sulbenicillin administered intravenously to rabbits. J. Takeda Res. Labs. 36: 78 82, 1977

9) NakaI, Y.; Y. Shirakawa, T. Fujita \& Z. Suzuoki: The metabolic fate of $\alpha$-sulphobenzylpenicillin in rats. Xenobiotica 2: 147 157, 1972 